\title{
Eagle 症候群の一例
}

三木 茂・島川 博美

淡河美智子・松浦健次郎

\section{A Gase of Eagle's Syndrome}

\section{Shigeru Miki, Hiromi Shimakawa, Michiko Aga and Kenjiro Matsuura}

(The University of Tokushima School of Medicine)

\begin{abstract}
Eagles's syndrome is charactarized by an elongated styloid process of the temporal bone. The present case in, 34-year-old male showed typical neuralgia, a dull, nagging pain in the throat, often localized to the tonsillar fossa and radiating to the ear. In this case the approach was through an external neck incision; about $25 \mathrm{~mm}$ of the bone was removed. One month later, the patient had no pain but slight foreign body sensation was noted at the vallecula epiglottica.
\end{abstract}

Key words: Eagle's syndrome, styloid process, neuralgia

\section{はじめに}

咽喉頭異常感を訴えるものや，頸部の疼痛な らびに肩凝りを訴えるものの中に，過長茎状突 起症が認められるととがある。しかし, 藥突舌 骨歎带完全化骨の報告は, 極めて少ない、今 回，きわめて稀有な茎乫舌，冒鞅带完全化骨の 1 例を経験したので報告する.

\section{症例}

患者: 34才, 男, 農林業.

主訴：右下䋶部痛及び開口障哇

既往歴：扁桃摘出

現病歴：数年来，肩こり之頸部捻転洔の耳へ の放散痛を覚えていたが, 数日前より痛みが増 強し, 開口障害が出現した。

初診封所見：体格優にて，栄䄳良好，熱発な く，右下䫈部から右耳介部にかけて腫脹あり. 自発痛を有しており, 境界不明膫な腫演を触知 する．開口障害あり．
レ線所見：Caldwell 氏法（図 1）下顎骨の 下方外側より舌雷へ向う陰影あり。

Waters 氏法（図 2) 上顎骨外側部に, 外側 から内側斜めに向う陰影あり.

頭部側面（切除片を合成（図 3）舌骨小角 へ向う二本の陰影あり.

頭部断屇（図4）途中, 偽関節を形成し, 膨 隆する。

嵒床検查：異常なし

処置及び経過：保存的加療にて経過観察とし ていたが, 20日後, 右末梢性顔面神経麻盘を併 発した。 保存的加療で顔面神経麻癘改善傾向を みたが, 疼痛改善の兆しがないため, 外切開に より，舌骨小解拈よびその上部をむ含めて，約 $2.5 \mathrm{~cm}$ 切除した.

手術後, 顔面神経麻痺の改善および疼痛の消 失を認めた。 


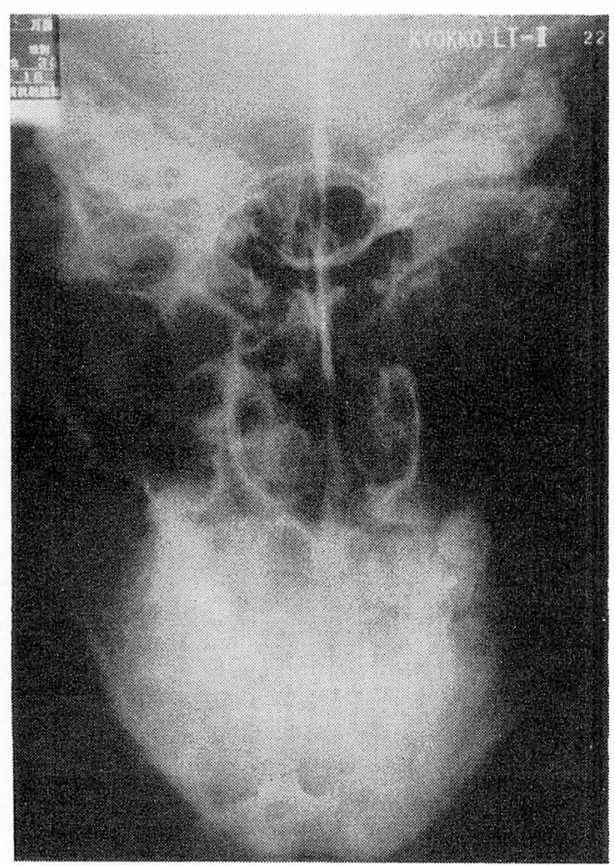

図

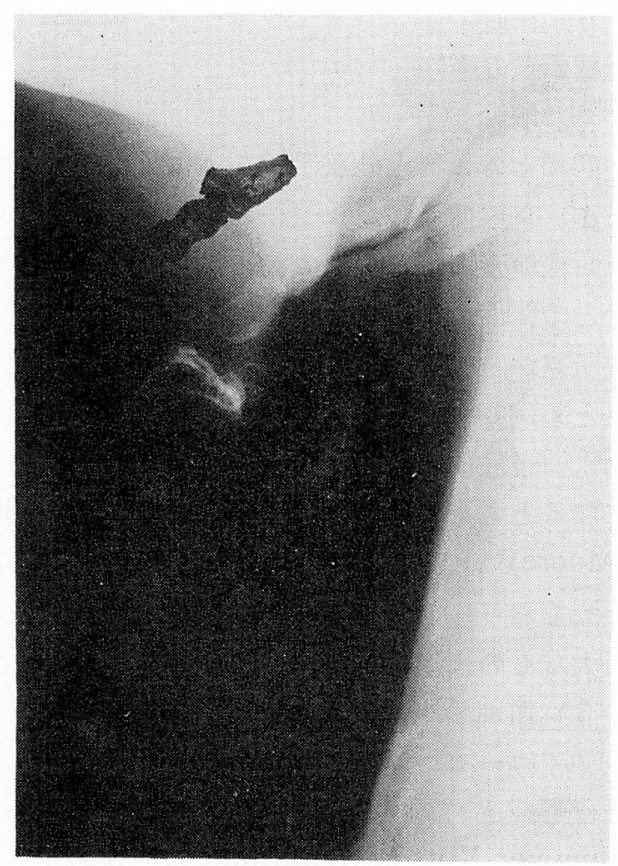

図 3

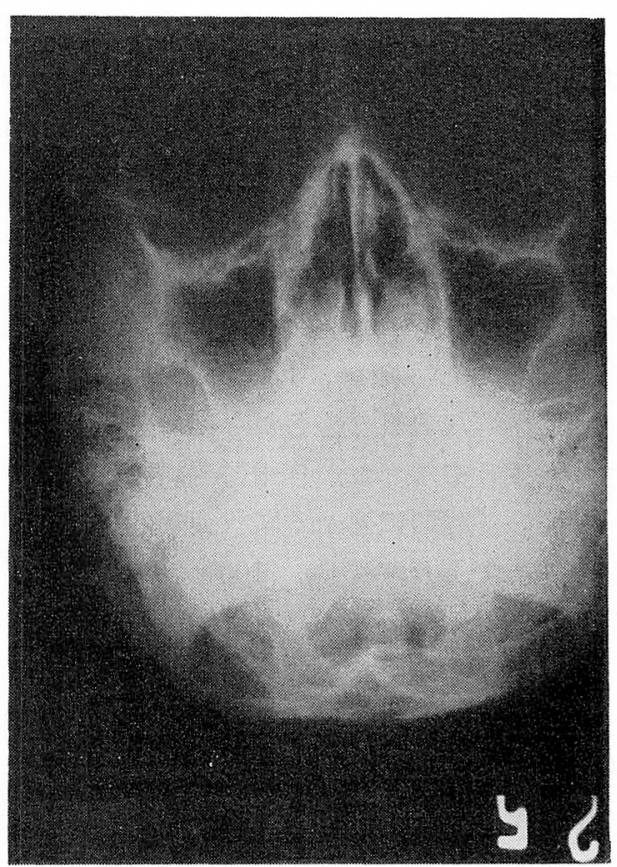

図 2

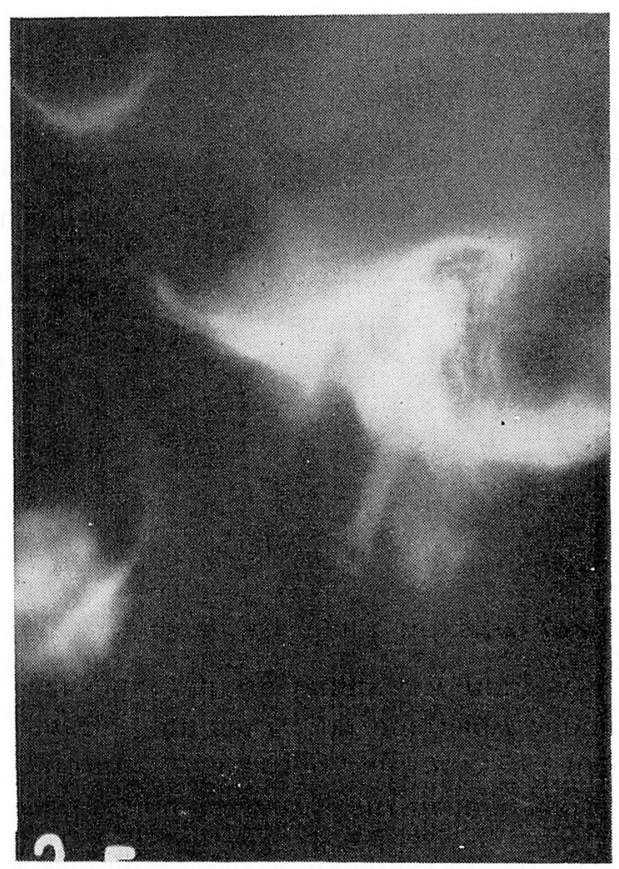

図 4 


\section{考察}

茎突舌骨靯带化骨についての最初の報告 は Marchetti (1652) ${ }^{1)}$ に見られる. Gruber $(1870)^{2)}$ は，2000 個以上の頭蓋骨を調査し 4.5 〜 $6.5 \mathrm{~cm}$ のの 11 例， $7.0 \mathrm{~cm}$ にふふおの 1 例を認 めたと報告した. Weinlechner $(1882)^{3)}$ は, 外科的処置により始好過長茎状㔖起症の症状 を消失させた。 von Eicken ${ }^{4}$ は，乙の疾患の 詳細な報告を行ない, Eagle $(1947)^{5)}$ は, 頸 動脈症候群なる概念をもたらし, 臨床上重要視 されるようになった，日本においては，田中， 笠井 ${ }^{6)}$ の『咽頭に達せる茎状笑起の 2 例』が最 初の報告であり, 以降， 100 余例の報告 ${ }^{7)}$ が行 なわれている。

1) 茎状乫起の発生

茎状突起は, 胎生学的に中胚葉の第 2 鰓弓 内の上部 (Reichert 軟骨) より発生するもの で, 骨や茎突舌骨靱带, 舌骨小角之始原を等 しくすると考えられている. Dwight は, 1. tympano-hyal（後に側頭骨岩様部底面に含ま れる), 2. stylo-hyal (茎状突起の大部分を形 成)，3. cerato-hyal（一般には，成人するに 従い茥状舌骨䩗帯になるが，化骨することもあ る), 4. hypo-hyal（舌骨小角を形成する), の 4 軟骨要素のうち茎状突起は, tympanohyal と stylo-hyal とよりなるとした. tympano-hyal は, 胎生初期飞出現し, 化骨は, その 1 年間にみられ, stylo-hyal は, 生後間 むなく出現し, 化骨は緩徐にすすみ思春期以降 に上部と骨癒合するが，しないととあある。

2 ) 異常荃状突起の発生機転 次の諸説がある.

\section{a) Merkel 説}

茎状突起, 茎状舌骨靬带, 舌骨小解の 3 者が 発育過程中に, 相互関係に失調をきたし, 形態 にいろいろな変化を生ずる. これは, 鰓弓の変 性あるいは退行現象に関係がある。

b) von Eicken 説

Henle, Bardeleben の解剖学説を基礎と し, 多数の茥状突起においての観察に立脚し茥
状舌骨靬带中に， 2 個の骨核があり，これが上 方に化骨し茎状突起と癒合し, 又一方，まれに は，下方に化骨し舌骨小解之癒合して長大な骨 桿を形成する.

c) Dwight 説

茎状舌骨笳の化骨による.

以上諸説のうち, 現在では, von Eicken 説 が支持されている.

3) 症候

自覚症状：ａ）咽頭異物感, 食物の咽頭停滞 感 b) 與䓵下痛, 放散性耳痛 c) 顔面痛, 頭 痛 d) 肩凝り.

他覚所見：a）咽頭壁の膨隆, 咽頭粘膜の発 赤, 慢性扁桃炎, 口蓋扁桃肥大 b ) 咽頭触診 による哭起の触知 c) 咽頭側壁および耳下部 圧痛点の存在.

4) 診断

a) 問揨

自覚症状として述べた項目や，牟田の報告に あある様に, 患者の家族歷 (過長茎状突起の家 族内発生）等を恥取する.

b ) 視診

咽頭壁の膨隆

c）触診

咽頭と外頸部との双手診

d） レ線所見

レ線検查による突起の長さ, 形態, 角度, 舌 骨との関係が明らかとなり，有用である。レ 線所見からは $40 \%$ 以内に笑起の結節状膨大を みとめ, occipito-frontal にて，よく現出さ

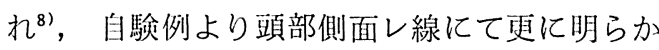
になると考えられる. 欧米人では, 平均 $25 \mathrm{~mm}$ (Moore $)^{9)}$, 日本人では, $16 \mathrm{~mm}$ (藤野) ${ }^{10)}$ と言 われており，我々のものは，100 mm以上に及び 長大なものに属する.

5 ) 鑑别診断

ノイローゼ, 舌根扁桃肥大, 顎関節症, 頸 椎変形症, 喉頭蓋変形, 上気道アレルギー, Plummer-Vinson Syndrome などが考えられ る. 
6) 治療

（1）保存的療法

a ) 薬物療法：自律神経遮断薬, 鎮痛薬, 局 所麻酥將注入療法

b）理学療法：超短波, 赤外線

（2）外科的療法

a) 骨折法

b ) 扁桃摘出術

c）突起切除術

経口法：一般に行う力法で, 型のごとく扁桃 摘出を行い, 扁桃窩触診により咨起を目標とし つつ, 軟部組織を釷的に剝離し笑起を露出さ せ, 切除する.

外頸部からの方法：下顎部後縁から胸鎖乳哭 筋前縁に沿う皮切を抏き，䫇二腹筋後腹を十分 に露出させ，舌骨小角を確認して上方へ辿ると 茎状突起が出現する．乙れを切除する.

過長茎状突起症は，今日において屯比較的ま れな疾患とされ，一般の認識は必ずしも十分で なく, 看過される可能性がある。本症は, 様々 な症状を伴って出現する．原因不明の咽頭症状 に際しては，本症も念頭にいれて診断を下す必 要がある。

\section{まとめ}

顔面神経麻盘と舌咽神経痛とをきたした過長 茎状突起症を経験した。外切開によって, 茎状 笑起を切除して, 症状の消失をみた。若干の文 献的考察を加えて報告した。

稿を終えるにあたり, 御校閲, 御指導を睗った小池 靖夫教授に深謝致します。

\section{参考文献}

1）车田哲三郎, 他：過長茎状突起症の臨床. 日耳鱼 52:697 703, 1959.

2) Gruber: Ueber enorm lange Processus styloideus der Schlafenbein. Virchows Archivf pathol Anatomie u Physiologie usw 50 : 232 234, 1870 .

3) Weinlechner: Abnorm langer processus styloideus als ursache von schlingbeschwerden. WienerMed Wochenschr $32 \mathrm{Nr} 5$, 1882.

4) von Eicken : Langer Processus styloideus als ursache fur schluckbeschwerden. Z Ohrenheilk $78: 63 \sim 72,1919$.

$5)$ Eagle : Elongated styloid process; further observations and a new syndrome. Arch Otolaryngol $47: 630 \sim 640,1948$.

6 ）田中文男, 他：咽頭に達せる茎状突起の二例. 日 耳奥 $27: 148 \sim 150,1921$.

7 ) 伊藤真郎：茎突舌骨靱带完全化骨の 1 例. 耳喉 $50: 2 ; 141 \sim 146,1978$.

8 ) 田中 明：異常菱状突起症に関する研究. 日耳臭 $63: 2371 \sim 2391,1960$,

9) Moore : Osseous and cartilaginous formations in the tonsils. J of Lar \& Otol 39 : 117 134, 195 208, 1924.

10）藤野政九郎：長大なる茎状特起に就て. 東北医学 報 $35: 1 \sim 7,1905$.

$$
\left(\begin{array}{l}
\text { 別刷請求先: 三木 茂 } \\
\text { 干770 德島県徳島県蔵本町 } 3 \\
\text { 徳島大学医学部耳鼻咽喉科学教室 }
\end{array}\right)
$$

